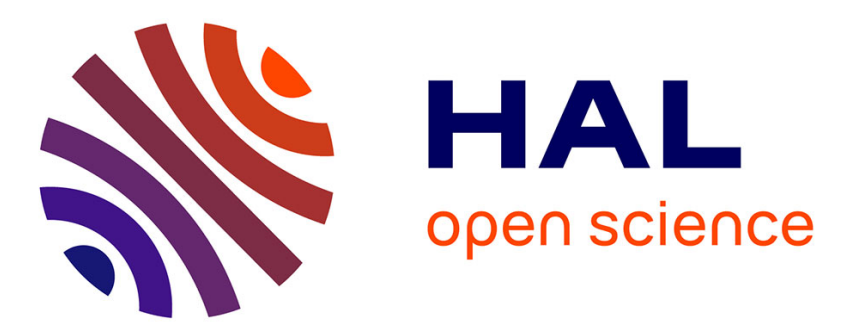

\title{
Seismic anisotropy, structures and geodynamics of continents Shear-wave splitting in the Appalachians and the Pyrenees: importance of the inherited tectonic fabric of the lithosphere
}

A Vauchez, Guilhem Barruol

\section{To cite this version:}

A Vauchez, Guilhem Barruol. Seismic anisotropy, structures and geodynamics of continents Shearwave splitting in the Appalachians and the Pyrenees: importance of the inherited tectonic fabric of the lithosphere. Physics of the Earth and Planetary Interiors, 1996, 95 (3-4), pp.127-138. 10.1016/00319201(95)03125-1 . hal-01389717

\section{HAL Id: hal-01389717 \\ https://hal.univ-reunion.fr/hal-01389717}

Submitted on 29 Oct 2016

HAL is a multi-disciplinary open access archive for the deposit and dissemination of scientific research documents, whether they are published or not. The documents may come from teaching and research institutions in France or abroad, or from public or private research centers.
L'archive ouverte pluridisciplinaire HAL, est destinée au dépôt et à la diffusion de documents scientifiques de niveau recherche, publiés ou non, émanant des établissements d'enseignement et de recherche français ou étrangers, des laboratoires publics ou privés. 
Seismic anisotropy, structures and geodynamics of continents

\title{
Shear-wave splitting in the Appalachians and the Pyrenees: importance of the inherited tectonic fabric of the lithosphere
}

\author{
A. Vauchez ${ }^{*}$, G. Barruol \\ Lahoratoire de Tectonophysique. CNRS-URA 1764, Université Montpellier II. Place E. Bataillon. F34095 Montpellier Cedex 05. France
}

Received 7 October 1994; accepted 31 August 1995

\begin{abstract}
Splitting of teleseismic shear waves has been measured in the Appalachians (eastem USA) and the Pyrenees (westem Europe) using data recorded by permanent and portable stations. From a comparison of the results, it appears that an interpretation of the recorded seismic anisotropy in terms of geodynamics is not straightforward. Successive geodynamic events have generated structures that may have resulted in a similar pattem of mantle flow and that therefore may have contributed in the development of the recorded anisotropy. Combining geological and geophysical arguments, it appears that the mantle anisotropy measured across the Appalachians and the Pyrenees may not be systematically Appalachian or Pyrenean in age but may be mainly due to a lithospheric structure formed during earlier major tectonic events, i.e. the Grenvillian and the Hercynian orogenies, respectively. We suggest that during major episodes of continent assembly, a pervasive tectonic fabric is developed in the lithospheric mantle. In the subsequent evolution of the continent, this fabric may induce a significant mechanical anisotropy that will drastically influence the mechanical behaviour of the lithosphere when submitted to new tectonic events.
\end{abstract}

\section{Shear-wave splitting on continents}

During the last decade, shear-wave splitting has been measured in many different continental areas to characterize the seismic anisotropy of continents. Although various possible sources have been recognized, there is a good consensus that the best candidate to generate teleseismic shear-wave splitting is the upper mantle (Vinnik et al., 1984, 1989a,b; Nicolas and Christensen, 1987; Silver and Chan, 1988; Babuska et al., 1993; Mainprice and Silver, 1993). Mantle rocks (xenoliths, peridotite bodies or ophiolites) systematically display a significant anisotropy (Nicolas and Christensen, 1987; Main-

\footnotetext{
* Corresponding author.
}

price and Silver, 1993). This anisotropy results from the good crystallographic preferred orientation of rock-forming minerals and from the single crystal anisotropic properties, especially of olivine, which is the primary upper-mantle mineral. This suggests that splitting of teleseismic shear waves is mostly related to the structure of the upper mantle, either owing to active (asthenospheric) or 'frozen' (lithospheric) mantle flow.

From the wealth of data accumulated, it appears that a common situation is a fast splitting polarization direction subparallel to the tectonic grain of the studied area (e.g. Silver and Chan, 1991; Bormann et al., 1993; James et al., 1996). Various, sometimes divergent, interpretations have been proposed to account for this observation. A much debated question 
is the depth range in which splitting of shear waves occurs. Does this anisotropy correspond to a 'frozen' lithospheric structure acquired during ancient orogenic events (e.g. Silver and Chan, 1988) or does it correspond to a present-day deformation of the asthenosphere by resistive drag beneath the moving rigid lithosphere (e.g. Bormann et al., 1993)? In the hypothesis of a lithospheric origin of shear-wave splitting, for realistic lithosphere thicknesses, the intrinsic seismic anisotropy observed in mantle rocks may account for the recorded delay times only if the frozen flow plane (foliation) is steeply dipping and flow direction (lineation) shallowly plunging (Mainprice et al., 1993). Various tectonic situations may explain such a fabric in the upper mantle. Silver and Chan (1988) suggested that in collision zones a preferred orientation of olivine $b$-axes in mantle rocks parallel to the bulk direction of shortening may result from a deformation of the lithospheric mantle by pure shear. Vauchez and Nicolas (1991) favoured simple shear through strike-slip faulting of the entire lithosphere. More recently, Nicolas (1993) suggested that during pre-orogenic extension, mantle flow parallel to rift walls occurred and entailed a pre-orogenic lithospheric fabric that was retained and largely influenced the deformation of the lithosphere during subsequent orogeny.

One of the main difficulties in deriving an accurate interpretation of shear-wave splitting is that the tectonic evolution of the lithosphere in many of the studied areas is poorly known. To avoid this problem, we examine splitting data from the Appalachians (eastern USA) and the Pyrenees (southern Europe). These two orogenic belts are of special interest: they have been extensively studied and their geodynamic evolution is well constrained by geological and geophysical data. In both orogens, a beltparallel fast shear-wave direction has been determined at most stations. In this paper, we consider the various hypotheses that may explain the measured seismic anisotropy. This highlights that, after an early orogenic event responsible for the main continent assembly in the two considered domains (i.e. the Grenville and the Hercynian orogenies for eastem North America and southern Europe, respectively), successive geodynamic events have generated structures with similar trends and thus may have contributed in the development of the recorded anisotropy. Finally, in the light of the mantle fabric suggested by shear-wave splitting, we discuss the possible causes of structural inheritance, especially during the break-up of continents.

\section{Shear-wave splitting in the Appalachians and the Pyrenees}

Splitting of teleseismic SKS, SKKS and PKS waves was recently measured in the Appalachians (Barruol et al., 1994) and in the Pyrenees (Souriau and Kassala, 1993; Barruol and Souriau, 1995). Splitting parameters $\phi$ (direction of polarization of the fast split shear wave) and $\delta t$ (the time lag between the arrival of the two split shear waves) were obtained using the algorithm described by Silver and Chan (1991).

In the Appalachians, data were recorded using three stations (DTMR, CSMR, BCMR) of a portable three-component, broad-band seismic network from the Carnegie Institution of Washington, which ran for 18 months during the period 1990-1992. Data from permanent stations in the eastern USA were also used to measure the splitting of teleseismic shear waves: 6 years of data were analysed for the Global Digital Seismographic Network (GDSN) Station SCP, 2 years for the Incorporated Research Institute for Seismology (IRIS) Stations HRV and CCM, 4 years for the GEOSCOPE Station WFM and 2 years for all the other stations from the US National Seismic Network (USNSN). In the Appalachians, values of $\delta t$ typically around $1.0 \mathrm{~s}$ are observed and $\phi$ is usually close to the strike of the regional foliation (N050-N060) for most of the stations located on the external units in the central part of the belt or in the Grenville belt, west of the Appalachians front (RSCP). In the internal domain, we obtained contrasting results at stations located in the Piedmont, which represents a lithospheric unit accreted to the North American lithosphere during the Appalachian orogeny: the fast polarization direction is oriented roughly N090 at WFM, HRV and LSCT, and no detectable splitting was found at DTMR and CEH. Results at MIAR, in the Ouachitas Mountains, which represent the continuation of the Appalachians to the SW, display a fast split wave oriented N080 parallel to the trend of the belt in Arkansas. At 
WMOK, in the Wichita Mountains, the fast polarization direction is oriented N120, parallel to the Amarillo-Wichita uplift. CCM and FVM, two stations located on the pre-Grenvillian basement, display a fast direction oriented around N040.

Data in the Pyrenees were recorded during a 5 months deployment of three-component portable stations across the belt from the European plate to the Iberian plate and by Station NEl0 from the Network of Autonomously Recording Stations (NARS) array (Dost, 1987). This experiment showed that the three stations located on the Iberian plate display large delay times $(1.3-1.5 \mathrm{~s})$ and uniform fast polarization directions (NlO0E), whereas the stations located north of the North Pyrenean Fault are characterized by smaller delay times $(0.5-1.0 \mathrm{~s})$ and varying fast polarization orientation (Barruol and Souriau, 1995). New preliminary results in the eastern Pyrenees display smaller variations of $\delta t$ through the North Pyrenean Fault but confirm the uniform $\phi$ direction ( $\mathrm{Nl00)}$ across the belt.

In both areas, for most stations $\phi$ is found to be close to the structural trend of the belt (Fig. 1) and $\delta t$, although variable, is usually around or higher than $1 \mathrm{~s}$. Possible sources for the observed anisotropy will be successively considered in the light of the geodynamic evolution of the Appalachians and the Pyrenees.

\subsection{Absolute plate motion}

Considering that for eastern North America the absolute plate motion (APM; Gordon, 1995) is close to the fast polarization direction of SKS waves, it may be argued that the source of the anisotropy lies in the asthenosphere flowing beneath the continent. This interpretation, however, requires similar fast polarization directions at nearby stations. The results obtained in the eastern USA (Barruol et al., 1994) do not fulfil this condition: the azimuth of the fast split shear wave is significantly oblique to the APM direction (N070) at WFM and HRV (N090), CBM and FVM (N40), or WMOK (N120), for instance (Fig. 1(a)), and no splitting has been detected at DTM and CEH. Moreover, these directions of fast wave correlate well with regional-scale lithospheric structures.

In the Pyrenees also it is difficult to link the splitting characteristics with plate motion. The current motion of westem Europe is slow (Minster and Jordan, 1978; Gripp and Gordon, 1990) and this makes more difficult an accurate determination of APM. However, recent models of plate motions (see the review in Gordon, 1995), suggest that western Eurasia is moving either northeastward or very slowly southwestward depending on the reference frame. In any case, there is a significant obliquity (about $50^{\circ}$ ) between the direction of the fast shear wave and the APM. Moreover, the recorded anisotropy parameters $(\phi$ and $\delta t$ ) display significant variations in a few tens of kilometres (Fig. 1(b)), which are in disagreement with the APM hypotheses (Barruol and Souriau, 1995). Barruol and Souriau (1995) showed that in the central Pyrenees, the North Pyrenean Fault, which is interpreted as the boundary between the Iberian and European plates, also forms a limit between two groups of anisotropy parameters, and that the variation of $\delta t$ is well correlated with the variation of the thickness of the lithosphere beneath the stations derived from studies of teleseismic $P$ residuals (Poupinet et al., 1992). From these arguments, they suggested that the source of the measured anisotropy is primarily located in the lithospheric mantle.

\subsection{Lithospheric shear zones}

In the internal domain of the Appalachians, the continental collision responsible for the formation of the belt resulted in an orogen-parallel displacement of lithospheric domains accommodated by continental-scale transcurrent shear zones parallel to the structural trend (Vauchez et al., 1987, 1993; Hinze and Hood, 1989). Regarding the Pyrenees, the early Cretaceous rotation of Iberia relative to Eurasia was accommodated by transcurrent motion along the North Pyrenean Fault (e.g. Choukroune (1992) and references therein). A possible explanation for the splitting characteristics is therefore to consider that the lithosphere beneath the stations has a fabric owing to the deformation associated with transcurrent lithospheric shear zones (Vauchez and Nicolas, 1991). Although this interpretation may account for the splitting characteristics in the internal domains, where transcurrent faulting dominates (e.g. Choukroune and Mattauer (1978) and Vauchez et al. (1987), for the Pyrenees and the Appalachians, re- 

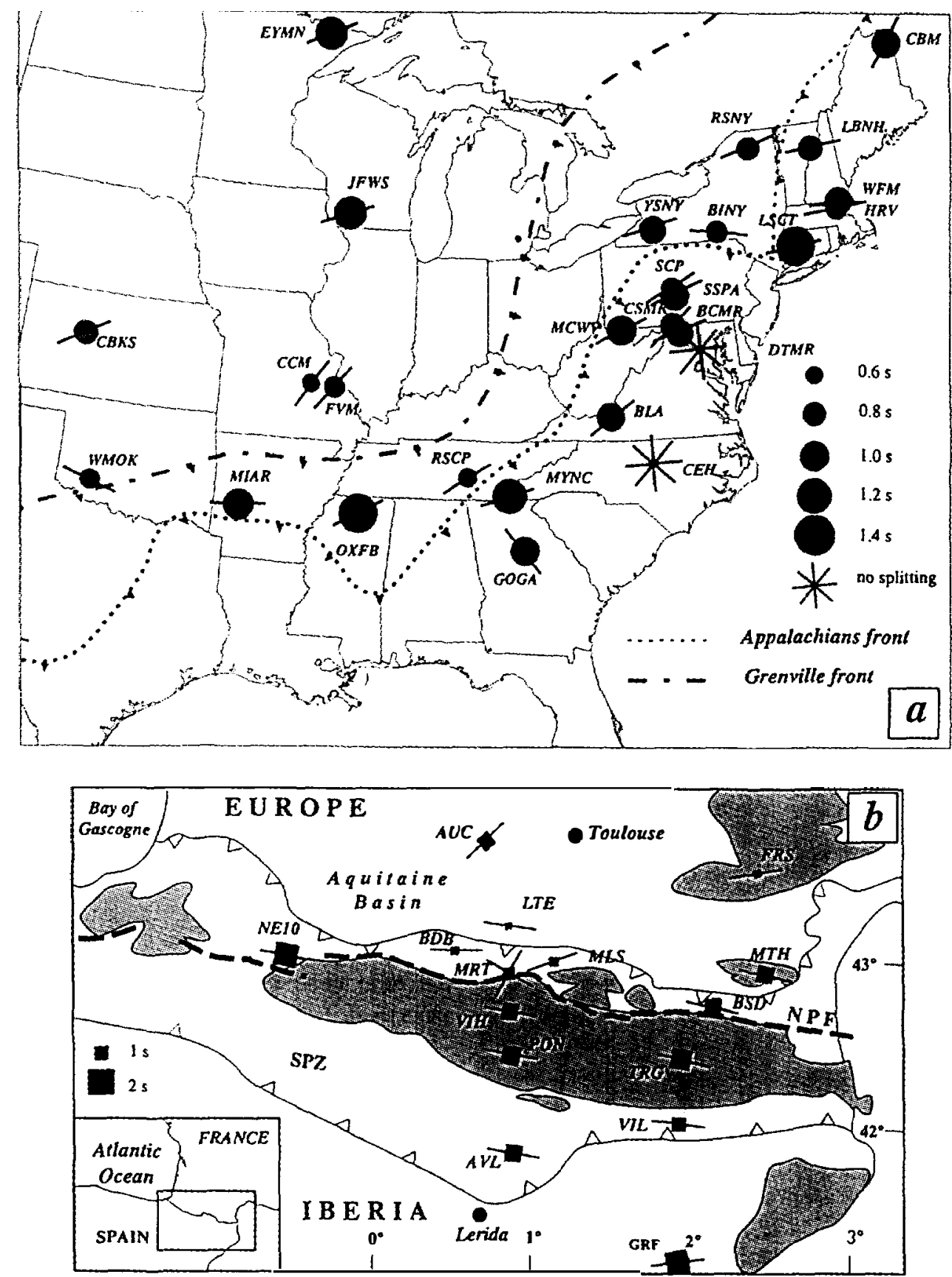

Fig. 1. Shear-wave splitting in the Appalachians (a) and the Pyrenees (b) (after Samarcq (1995) and Barruol and Souriau (1995)). Circle (a) and square (b) size is proportional to the delay time, and the fast polarization directions are indicated by the black lines. (In the Appalachians, note the absence of anisotropy at CEH and DTMR.) In the Pyrenees, shaded areas indicate exposure of the Hercynian basement. NPF, North Pyrenean Fault. 
spectively), it does not hold for the belt-parallel fast shear waves in the external domains of the belts. Seismic reflection profiles across the Appalachians (Cook et al., 1979) and the Pyrenees (Choukroune and ECORS Pyrenees Team, 1989; Choukroune, 1992) strongly suggest that only a faint deformation, limited to the shallow crust, affected the lithosphere of the external domains (Fig. 2). Consequently, the seismic anisotropy recorded in these external domains (for instance, at SCP in the Appalachians and at AVL in the Pyrenees) is unlikely to be related to a pervasive fabric of the lithosphere developed during the formation of the belts.

\subsection{Pre-orogenic rifting}

Pre-orogenic rift-parallel mantle flow (Nicolas, 1993) may account, at least locally, for the lithospheric fabric in the two considered belts. In the Appalachians, the eastern margin of the North American plate (Laurentia) was formed during an Early Palaeozoic episode of rifting. This resulted in the opening of the proto-Atlantic (Iapetus) Ocean, and, according to Dalziel et al. (1994), in the disruption of the Gondwana supercontinent and the separation of Laurentia from Gondwana. Opening of an oceanic basin during the late Precambrian-early Cambrian

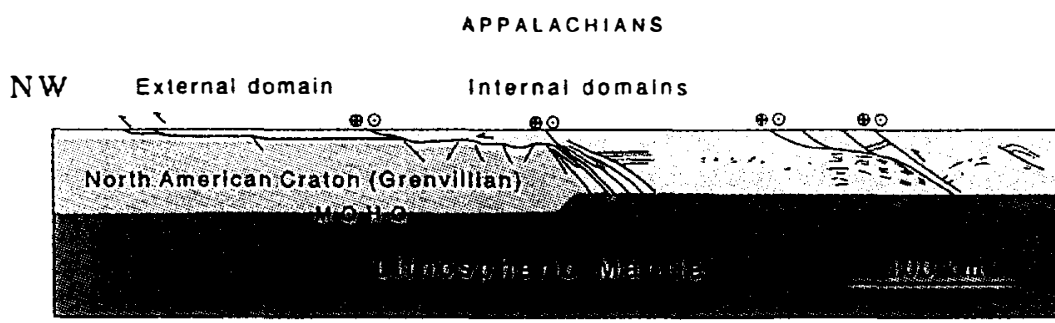

a

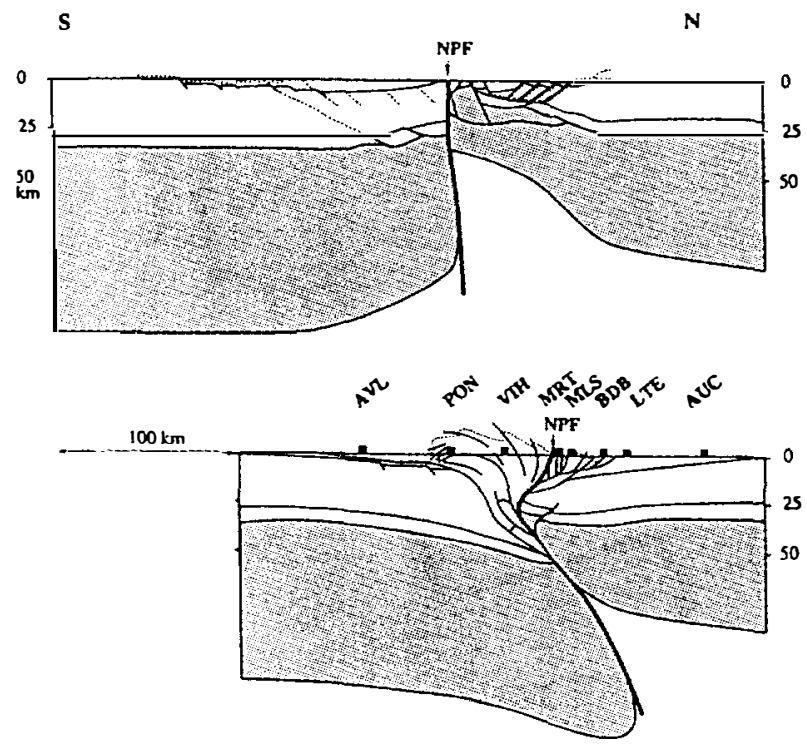

b

Fig. 2. Interpretative geological cross-sections in the southern Appalachians (a) and the Pyrenees (b). (a) is an interpretation of the crustal structures of the COCORP seismic profile by Hatcher and Zietz (1980) and (b) is a compilation of the interpretations by Choukroune and ECORS Pyrenees Team (1989) for the crust, and by (Mattauer, 1990) for the lithospheric mantle, of the ECORS seismic profile. In both cases, the external domain of the belt appears to have escaped pervasive reworking. 
and its subsequent closure during the formation of the Appalachians is especially supported by the presence of an ultramafic belt (Hess, 1955) that stretches all along the belt and in which ophiolites have been recognized (e.g. Drake and Morgan, 1981). The orientation of the initial rift (Fig. 3) was close from the trend of the present-day Appalachians belt (e.g. Thomas, 1977, 1991). Seismic profiling (e.g. Cook et al., 1979; Owens et al., 1984) as well as gravity studies suggest that subsidiary rifts, formed during disruption of the eastern North American continent, have been preserved in the buried North American basement.

In the Pyrenees, lithospheric thinning occurred beneath the North Pyrenean Zone (the palaeoEuropean margin). Pull-apart basins formed during the Albian-Cenomanian displacement of the Iberian Peninsula along the North Pyrenean Fault, related to the opening of the Bay of Biscay in the northern Atlantic (e.g. Choukroune (1992) and references therein). These basins (a possible reconstruction is shown Fig. 4) are clearly associated with a thin crust and lithosphere (a proposed cross-section of the system at that time is shown in Fig. 2(b), top). Evidence from gravity (Torne et al., 1989), seismic refraction (Gallart et al., 1981) and seismic reflection (Choukroune and ECORS Pyrenees Team, 1989) suggests a thick Iberian crust and a thin crust beneath the European margin. Teleseismic P-residual studies (Poupinet et al., 1992) are compatible with a thinner lithosphere beneath the North Pyrenean Zone than beneath the Iberian plate. The presence of numerous lherzolite massifs in the North Pyrenean Zone emplaced in sedimentary rocks together with high-temperature metamorphism (Golberg and Leyreloup, 1990) also argue for an extremely thinned lithosphere beneath the North Pyrenean Zone during the rotation of Iberia (Vielzeuf and Komprobst, 1984). The evidence for lithospheric thinning is restricted to the North Pyrenean Zone. Rift-parallel

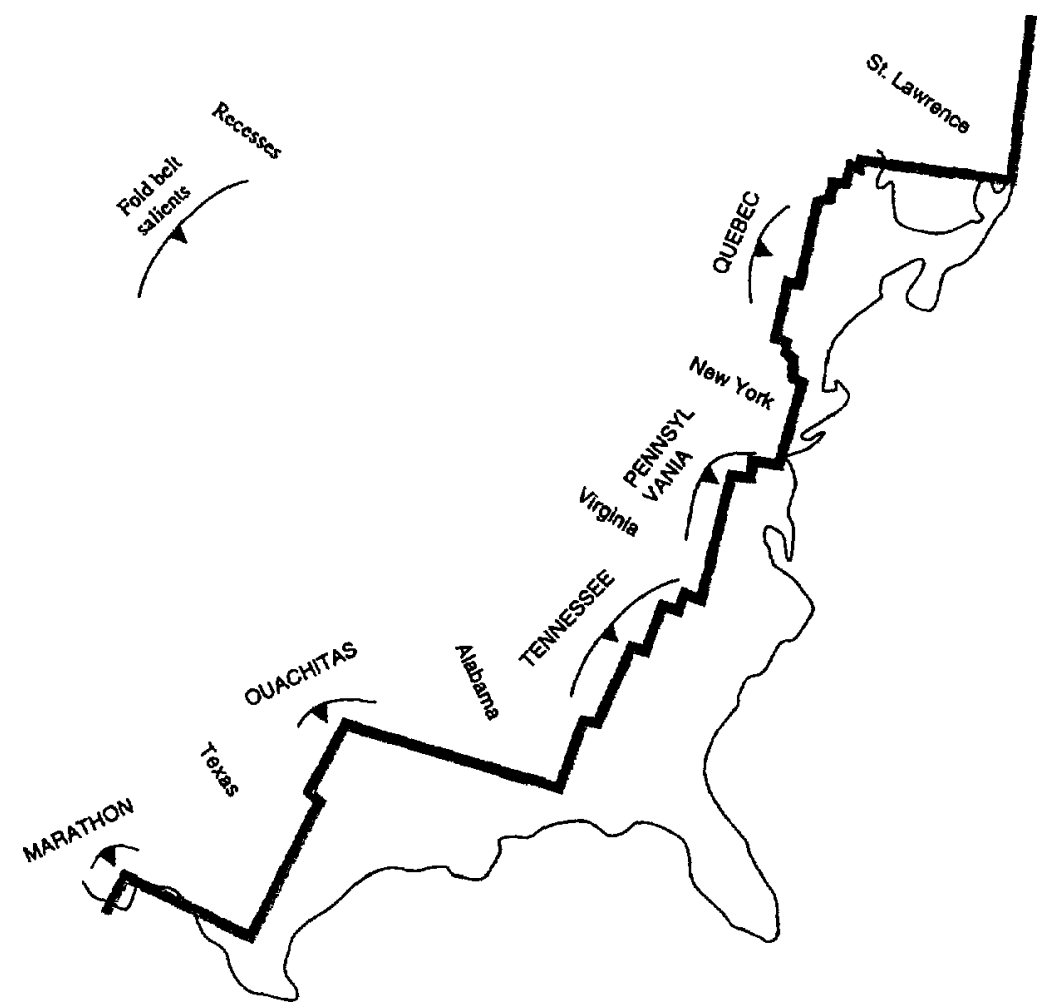

Fig. 3. Map showing the initial rift system of the Iapetus Ocean (Upper Proterozoic-Lower Palaeozoic) in eastem North America. Salients and recesses of the Appalachians are correlated with the geometry of the ridge-transform system. After Thomas (1991). 


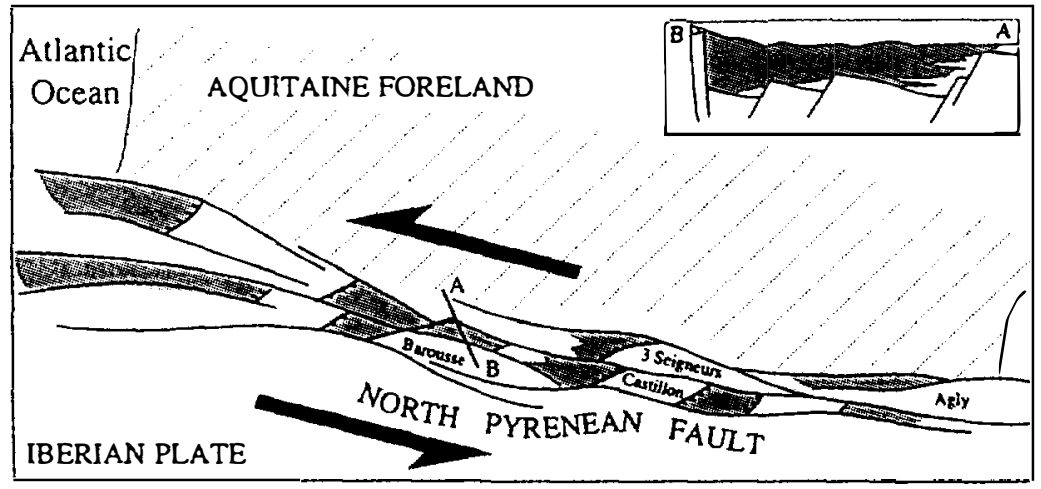

Fig. 4. Possible reconstruction of the geometry of the pull-apart basins formed during the displacement of the Iberian plate along the North Pyrenean Fault during the middle Cretaceous. Insert shows a schematic section across a pull-apart basin. After Choukroune (1992).

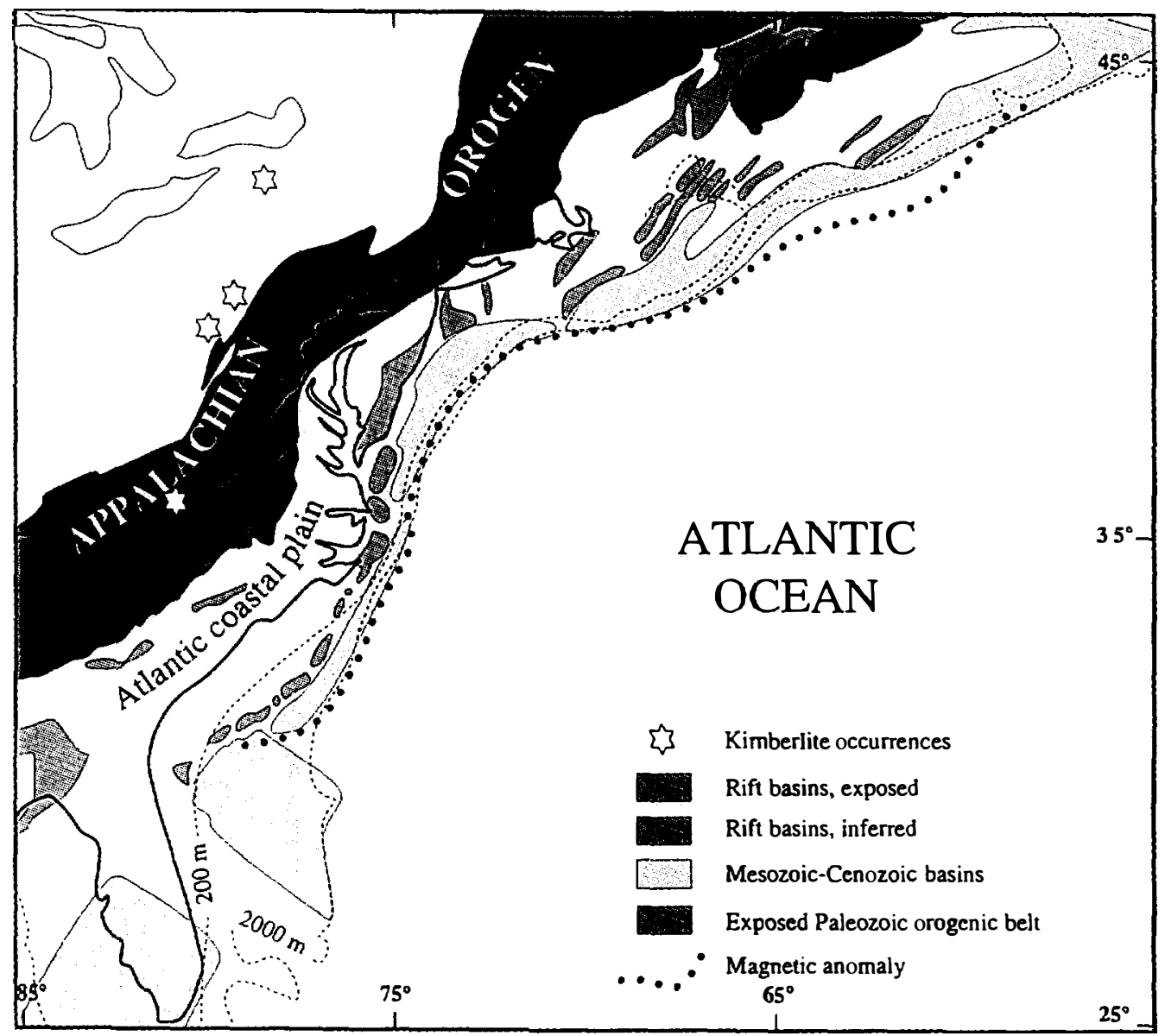

Fig. 5. Post-orogenic rift-basins formed on the margin of eastem North America in relation to the opening of the Atlantic Ocean (simplified from Sheridan, 1989). Kimberlite occurrences in the external domain of the belt are also shown. The east coast magnetic anomaly delineates approximately the boundary between the transitional crust and the oceanic crust. (Note the good parallelism between the trend of the Appalachian belt, the Triassic and Mesozoic rifts and the magnetic anomaly.) 
mantle flow therefore may be invoked to explain the seismic anisotropy recorded on the palaeo-European margin but fails to explain data from the southern domain of the belt.

\subsection{Post-orogenic rifting}

Rifting subsequent to an orogeny may also have contributed to the fabric of the lithosphere responsible for the recorded anisotropy. In the eastem North American lithosphere, a clear parallelism between the Appalachians' structural trend, the continent margin, and the main magnetic anomalies that mark the growth of the ocean (Fig. 5) highlights that the initial rift propagated southward along the internal domain of the belt. Evidence of local deformation of the lithosphere related to the Atlantic Ocean opening is common across the belt. Triassic rifts, elongated parallel to the Appalachians' structural grain, have been formed in the eastern domain, from the Piedmont to the continental margin. Moreover, several occurrences of rocks with kimberlite affinity have been emplaced in the external domain (Blue Ridge) and even beyond the tectonic front of the belt, in the
Cumberland plateau. Their emplacement has been interpreted as an asthenospheric upwelling occurring during the early stages of the North Atlantic rifting (Taylor, 1984). This suggests that the deformation field associated with the opening of the ocean penetrated far inland. It remains difficult, however, to believe that rift-parallel mantle flow may have pervasively affected the lithospheric mantle structure over such a large area. In the case of the Pyrenees, this process should be ruled out, as this area did not undergo post-orogenic rifting.

\subsection{Inherited lithospheric fabric}

An alternative explanation for the anisotropy recorded in the external domain of both the Appalachians and the Pyrenees is to consider that the fabric of the lithospheric mantle responsible for the splitting of shear waves did not develop during the Appalachian and the Pyrenean orogenies, but during an earlier tectonic episode.

The two considered belts lie on the edge of continents that have been largely shaped during an earlier, major event of continent assembly: the

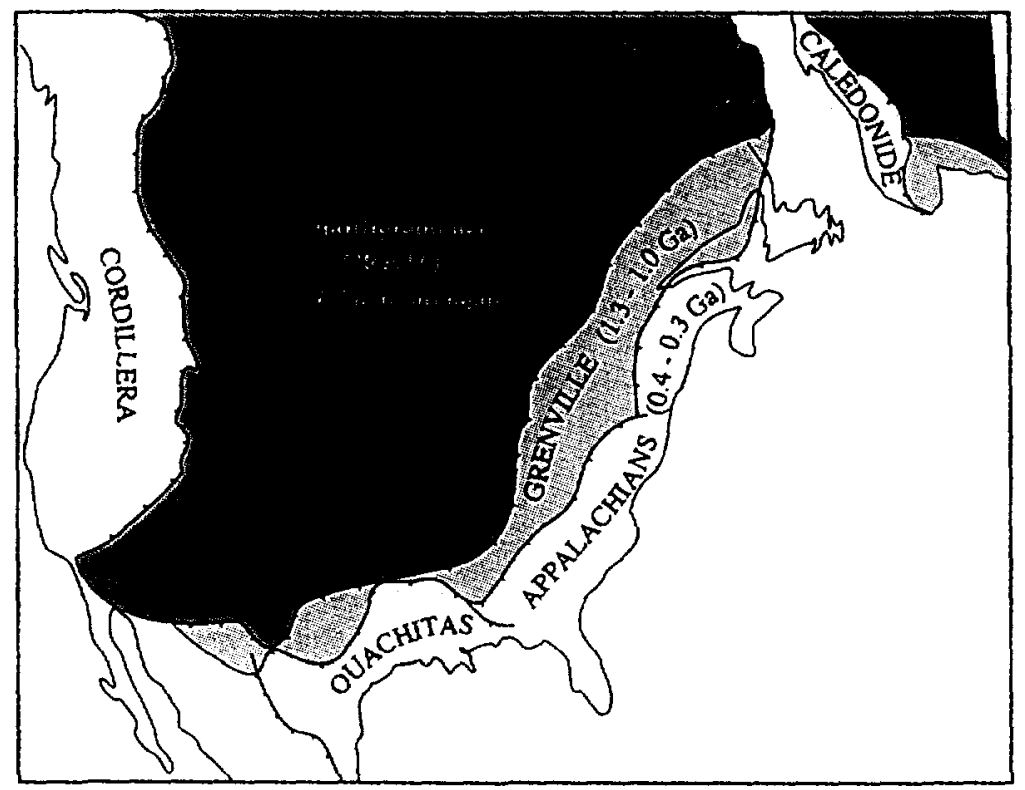

Fig. 6. Schematic map showing the parallelism between the Appalachian-Ouachita orogen and the Grenville belt in eastern North America. Modified from Hoffman (1989). 
Grenvillian orogeny for the Appalachians and the Hercynian orogeny for the Pyrenees. Considering that during these orogenies a strip of continental lithosphere exceeding $1000 \mathrm{~km}$ in width was deeply deformed, it may be expected that a pervasive lithospheric fabric was developed. It is, in fact, during these events that the eastern North American and the western European continents were built.

The NE-SW-trending Appalachian belt and east-west-trending Ouachitas Mountains are consistently parallel with the Grenville belt (Fig. 6), which wraps around the old cratonic nucleus of North America. In the Canadian branch of the Grenville belt, the main thrust faults and limits between the tectono-metamorphic zones trend northeastward (Hoffman, 1989). Southward, exposures are scarce, but magnetic and gravimetric anomaly patterns characteristic of the different domains of the belt defined in the northem area allow us to identify buried terranes and extrapolate their limits (Hinze and Hood, 1989). This leads us to suggest that the seismic anisotropy recorded at the stations located in the external Appalachians, on the sedimentary nappes overthrusting the Grenvillian basement, is the signature of a Grenvillian lithospheric structure. That would be the case, for instance, for SCP, MCWV, MYNC, CSMR and BLA, which display fast split shear waves oriented N050-070.

The reconstruction of the Variscan belt (Matte, 1991) also displays a good parallelism between the Hercynian structures and the Pyrenees belt. Most of the pervasive structures in the Axial Zone of the Pyrenees are Hercynian in age and oriented parallel to the belt (e.g. Zwart, 1986). Carreras and Cirès (1986), for instance, showed that the main Hercynian structures are oriented parallel to the North Pyrenean Fault in the eastern Pyrenees. In the central Pyrenees, Hercynian regional foliation trends east-west and is steeply dipping (Zwart, 1986). Vissers (1992) found a consistent pattern of shallowly plunging Hercynian lineations oriented parallel to the belt throughout the axial zone. These observations lead us to suggest that the roughly east-west fast directions found south of the North Pyrenean Fault may be inherited from a Hercynian lithospheric structure. There is, furthermore, a striking similarity between the splitting parameters obtained in the Iberian Pyrenees and those obtained at the Toledo station in central Spain (Vinnik et al., 1989b; Silver and Chan, 1991), which also give roughly east-west fast waves parallel to the Hercynian crustal fabric.

\section{Evolution of continents and tectonic inheritance}

Considering the evolution of the eastern margin of the North American continent, it appears that after the Grenville orogeny $(1.3-1.0 \mathrm{Ga})$ all structures, including the Appalachian belt and the pre- and post-Appalachian rifts, formed parallel to the structural grain of the Grenville belt. Between $0.8 \mathrm{Ga}$ and $0.6 \mathrm{Ga}$ (i.e. more than $0.5 \mathrm{Ga}$ after the Grenville orogeny) episodic rifting resulted in the break-up of the Gondwana supercontinent parallel to the strike of the belt and in the formation of a passive margin. At the end of a period of ocean opening, the east American margin became convergent, and underwent the accretion of several exotic terranes and finally a collision with Africa, resulting in the building of a new belt (the Appalachians-Ouachitas system) that fits the older one almost exactly. Then a similar evolution started again with the break-up of the amalgamated continent along the Appalachians internal domain and the opening of the North Atlantic Ocean.

A similar observation is made in the Pyrenees during the opening of the Bay of Biscay 120-80 m.y. ago. The initial break-up between Europe and Iberia was certainly dominantly transcurrent (see review by Choukroune (1992)): the North Pyrenean Fault formed parallel to the strike of the Hercynian belt, and Iberia began to translate southeastward along the fault. During the Upper Cretaceous, narrow basins elongated parallel to the trend of the North Pyrenean Fault, and therefore to the Hercynian belt, have been active. Finally, the convergence between Iberia and Europe resulted in the building of the Pyrenees with a structural trend parallel to the Hercynian grain.

These two examples highlight the importance of structural inheritance in the evolution of continents. Although this has already been stressed by many workers (e.g. Wilson, 1966; Vinck et al., 1984; Dunbar and Sawyer, 1988, 1989), and several explanations of this behaviour have been suggested, the mechanism through which tectonic inheritance arises still remains unclear. For eastern North America, a 
rheological heterogeneity of the lithosphere owing to the presence of the old cratonic nucleus with a cold and thick lithosphere could be invoked to explain continent break-up parallel to the boundary of the old craton. This explanation, however, remains unlikely because the rupture did not occur at the interface between the two domains, but far eastward within the internal domain of the Grenville belt. Furthermore, in the Pyrenees, the absence of an old nucleus precludes an influence of rheological heterogeneities in the break-up between Europe and Iberia.

The Grenvillian and Hercynian orogenies were responsible for the main assembly of the continental lithosphere of eastem North America and westem Europe, and resulted in a tectonic fabric consistent over thousands of kilometres. The characteristics of shear-wave splitting in the external domain of the Appalachian and the Pyrenean belts, i.e. the tendency for the fast shear wave to be polarized in a plane parallel to the structural grain of the Grenville and the Hercynian belts and time lags frequently exceeding $1 \mathrm{~s}$, probably denote a pervasive structural fabric over the entire thickness of the lithospheric mantle. We suggest an alternative explanation from our observations: the source of the tectonic inheritance in the break-up of the Grenvillian and the Hercynian lithosphere could be a mechanical anisotropy of the lithospheric mantle of orogenic areas caused by a well-developed fabric within the lithospheric mantle. The Grenvillian or Hercynian lithospheric fabric may have been substantially reworked in the internal domain of the belts during the Appalachian or the Pyrenean orogeny, but remained almost undeformed beneath the external domain. This is in agreement with a width of the orogens considerably narrower at the level of the lithospheric mantle than at the surface.

\section{Conclusions}

The growing body of data available on the splitting of teleseismic shear waves on continents supports the idea that the main source of anisotropy lies in the lithosphere. A consistent parallelism between the orientation of the fast split shear wave and the trend of the continental-scale tectonic structures of the considered region is frequently observed, and this hints that the anisotropic structure responsible for shear-wave splitting is probably the frozen deformation fabric of the lithosphere formed during past orogenic events. Shear-wave splitting within the deformed asthenosphere beneath continental plates may also contribute, but cannot explain all the evidence, except in a few areas.

Interpreting shear-wave splitting in terms of geodynamic processes, however, is not straightforward. In the Appalachians and the Pyrenees, where teleseismic shear-wave splitting is characterized by a fast wave dominantly parallel to the structural trend of the belt, successive events have generated structures that have similar trends and are probably associated with similar mantle flow patterns. These structures may have therefore contributed in the development of the recorded anisotropy, although their respective contribution is difficult to recognize. In both belts, splitting characteristics are probably related in large part to the pre-orogenic structure of the lithosphere developed during an earlier, major event. During subsequent orogenic events, the lithospheres of eastem North America and western Europe, respectively built during the Grenvillian and the Hercynian orogenies, seem to have largely escaped pervasive reworking, except in the internal domains of the Appalachians and the Pyrenees, and in the domain where the initial rifting of the Atlantic Ocean occurred. The evolution of these two areas during subsequent deformations, rifting and splitting of continents, as well as accretion of oceanic arcs and microplates and continent-continent collision, is characterized by the development of new tectonic structures that match the initial fabric of the lithosphere formed during the main event of continent assembly.

Structural inheritance in the break-up of continents is an obvious process in many places throughout the world at least since the Neoproterozoic. The rupture of the continental lithosphere appears to propagate along the pre-existing orogenic fabric of the continents. Considering that shear-wave splitting parameters are in agreement with a steeply dipping fossil flow plane (foliation) and a shallowly plunging flow direction (lineation) in the lithospheric mantle, we propose that structural inheritance arises through mechanical anisotropy of the lithospheric mantle owing to a pervasive inherited fabric. 


\section{Acknowledgements}

This work benefited from many fruitful discussions with K. Burke, D. Mainprice, A. Nicolas, A. Souriau, P. Silver and A. Tommasi. We are indebted to $G$. Ranalli and M. Daignières for helpful reviews. We acknowledge financial support from CNRS-INSU (Action Tomographie), Intemational Lithosphere Programme, and CNRS-NSF collaboration programme.

\section{References}

Babuska, V., Plomerova, J. and Sileny, J., 1993. Models of seismic anisotropy in the deep continental lithosphere. Phys. Earth Planet. Inter., 78: 167-191.

Barruol, G. and Souriau, A., 1995. Anisotropy beneath the Pyrenees range from teleseismic shear wave splitting. Geophys. Res. Lett., 22: 493-496.

Barruol, G., Silver, P.G., Vauchez, A. and Souriau, A., 1994. Seismic anisotropy in orogenic areas: case of the Pyrenees and the Appalachians. Am. Geophys. Union Spring Meeting, Baltimore, MD. American Geophysical Union, Washington, DC.

Bormann, P., Burghardt, P.T., Makeyeva, L.I. and Vinnik, L.P., 1993. Teleseismic shear-wave splitting and deformations in central Europe. Phys. Earth Planet. Inter., 78: 157-166.

Carreras, J. and Cirès, J., 1986. The geological significance of the western termination of the Mérens fault at Port Vell (Central Pyrenees). Tectonophysics, 129: 99-114.

Choukroune, P., 1992. Tectonic evolution of the Pyrenees. Annu. Rev. Earth Planet. Sci., 20: 143-158.

Choukroune, P. and ECORS Pyrenees Team, 1989. The ECORS Pyrenean deep seismic profile reflection data and the overall structure of an orogenic belt. Tectonics, 8: 23-39.

Choukroune, P. and Mattauer, M., 1978. Tectonique des plaques et Pyrenées: sur le fonctionnement de la faille transformante nord-pyrénéenne; comparaison avec les modèles actuels. Bull. Soc. Geol. Fr., 20: 689-700.

Cook, F.A., Albaugh, D.S., Brown, L.D., Oliver, J.E. and Hatcher, R.D., 1979. Thin-skinned tectonics in the crystalline southern Appalachians; COCORP seismic-reflection profiling of the Blue Ridge and Piedmont. Geology, 7: 563-567.

Dalziel, I.W.D., Dalla Salda, L.H. and Gahagan, L.M., 1994. Paleozoic Laurentia-Gondwana interaction and the origin of the Appalachian-Andean mountain system. Geol. Soc. Am. Bull., 106: 243-252.

Dost, B., 1987. The NARS array: a seismic experiment in western Europe. Geol. Ultraiectina, 47: $147 \mathrm{pp}$.

Drake, Jr., A.A. and Morgan, B.A., 1981. The Piney Branch complex - a metamorphosed fragment of the central Appalachian ophiolite in northem Virginia. Am. J. Sci., 281: 484-508.
Dunbar, J.A. and Sawyer, D.S., 1988. Continental rifting at pre-existing lithospheric weaknesses. Nature, 333: 450-452.

Dunbar, J.A. and Sawyer, D.S., 1989. How preexisting weaknesses control the style of continental breakup. J. Geophys. Res., 94: 7278-7292.

Gallart, J., Banda, E. and Daignières, M., 1981. Crustal structure of the Paleozoic Axial Zone of the Pyrenees and the transition of the North Pyrenean Zone. Ann. Geophys., 37: 457-480.

Golberg, J.M. and Leyreloup, A.F., 1990. High temperature-low pressure Cretaceous metamorphism related to crustal thinning (Eastem North Pyrenean Zone, France). Contrib. Mineral. Petrol., 104: 194-207.

Gordon, R.G., 1995. Present plate motions and plate boundaries. In: T.J. Ahrens (Editor), Global Earth Physics-a Handbook of Physical Constants, 1. American Geophysical Union, Washington, DC, pp. 66-87.

Gripp, A.E. and Gordon, R.G., 1990. Current plate velocities relative to the hotspots incorporating the Nuvel-1 global plate motion model. Geophys. Res. Lett., 17: 1109-1112.

Hatcher, R.D. and Zietz, I., 1980. Tectonic implications of regional aeromagnetic and gravity data from the southem Appalachians. In: D.R. Wones (Editor), The Caledonides in the USA. Virginia Polytech. Inst. Mem., 2: 235-244.

Hess, H.H., 1955. Serpentinites, orogeny, and epeirogeny. Geol. Soc. Am. Spec. Pap., 62: 391-408.

Hinze, W.H. and Hood, P.J., 1989. The magnetic anomaly map of North America; a new tool for regional geologic mapping. In: A.W. Bally and A.R. Palmer (Editors), The Geology of North America-an Overview, A. Geological Society of America, Boulder, CO, pp. 29-38.

Hoffman, P.F., 1989. Precambrian geology and tectonic history of North America. In: A.W. Bally and A.R. Palmer (Editors), The Geology of North America-an Overview, A. Geological Society of America, Boulder, CO, pp. 447-512.

James, D.E., Assumpção, M., Snoke, J.A., Ribotta, L.C. and Kuehnel, R., 1996. Seismic studies of continental lithosphere beneath SE Brazil. Rev. Soc. Bras. Geofis., in press.

Mainprice, D. and Silver, P.G., 1993. Interpretation of SKS-waves using samples from the subcontinental lithosphere. Phys. Earth Planet. Inter., 78: 257-280.

Mainprice, D., Vauchez, A. and Montagner, J.P., 1993. Seismic anisotropy in the mantle and geodynamics of orogenic belts. Preface. Phys. Earth Planet. Inter., 78: vii-xi.

Mattauer, M., 1990. Une autre interprétation du profil ECORS Pyrénées. Bull. Soc. Geol. Fr., VI(8): 307-311.

Matte, P., 1991. Accretionary history and crustal evolution of the Variscan belt in western Europe. Tectonophysics, 196: 309337.

Minster, J.B. and Jordan, T.H., 1978. Present-day plate motion. J. Geophys. Res., 83: 5331-5354.

Nicolas, A., 1993. Why fast polarization directions of SKS seismic waves are parallel to mountain belts? Phys. Earth Planet. Inter., 78: 337-342.

Nicolas, A. and Christensen, N.I., 1987. Formation of anisotropy in upper mantle peridotites-a review. In: K. Fuchs and C. Froidevaux (Editors), Composition, Structure and Dynamics of 
the Lithosphere-Asthenosphere System, Vol. 16. American Geophysical Union, Washington, DC, pp. 111-123.

Owens, T.J., Zandt, G. and Taylor, S.R., 1984. Seismic evidence for an ancient rift beneath the Cumberland Plateau, Tennessee: a detailed analysis of broadband teleseismic $\mathbf{P}$ waveforms. J. Geophys. Res., 89: 7783-7795.

Poupinet, G., Souriau, A., Vadell, M. and Njike-Kassala, J.D., 1992. Constraints on the lithospheric structure beneath the North Pyrenean Fault from teleseismic observations. Geology, 20: $157-160$.

Samarcq, F., 1995. Anisotropie sismique et structure du manteau lithosphérique sous les Pyrénées orientales. Unpublished Diplome d'Etudes Approfondies, University of Montpellier, $62 \mathrm{pp}$.

Sheridan, R.E., 1989. The Atlantic passive margin. In: A.W. Bally and A.R. Palmer (Editors), The Geology of North Americaan Overview, A. Geological Society of America, Boulder, CO, pp. 81-96.

Silver, P.G. and Chan, W., 1988. Implications for continental structure and evolution from seismic anisotropy. Nature, 335: $34-39$.

Silver, P.G. and Chan, W.W., 1991. Shear wave splitting and subcontinental mantle deformation. J. Geophys. Res., 96: 16429-16454.

Souriau, A. and Kassala, J.-D.N., 1993. Anisotropy beneath the North Pyrenean fault. Phys. Earth Planet. Inter., 78: 239-244.

Taylor, L.A., 1984. Kimberlitic magmatism in the eastern United States: relationships to mid-Atlantic tectonism. In: J. Komprobst (Editor), Kimberlites. I: Kimberlites and Related Rocks. Elsevier, Amsterdam, pp. 417-424.

Thomas, W.A., 1977. Evolution of Appalachian salients and recesses from reentrants and promontories in the continental margin. Am. J. Sci., 277: 1233-1278.

Thomas, W.A., 1991. The Appalachian-Ouachita rifted margin of southeastem North America. Geol. Soc. Am. Bull., 103: 415431.

Tome, M., Cabissole, B.D., Bayer, R., Casas, A., Daignières, M. and Ribero, A.. 1989. Gravity constraints on the deep structures of the Pyrenean belt along the ECORS profile. Tectonophysics, 166: 105-116

Vauchez, A. and Nicolas, A., 1991. Mountain building: strikeparallel displacements and mantle anisotropy. Tectonophysics 185: 183-201.

Vauchez, A., Kessler, S., Lécorché, J.P. and Villeneuve, M., 1987. Southward extrusion tectonics during Carboniferous Africa-North America collision. Tectonophysics, 142: 317322.

Vauchez, A., Babaei, H. and Babaei, A., 1993. Orogen-parallel tangential motion in the late Devonian-early Carboniferous southem Appalachians internides. Can. J. Earth Sci., 30: 1297-1305.

Vielzeuf, D. and Kornprobst, J., 1984. Crustal splitting and the emplacement of the Pyrenean lherzolites and granulites. Earth Planet. Sci. Lett., 67: 87-96.

Vinck, G.E., Morgan, W.J. and Zhao, W.-L., 1984. Preferential rifting of continents: a source of displaced terranes. J. Geophys. Res., 89: 10072-10076.

Vinnik, L.P., Kosarev, G.L. and Makeyeva, L.I., 1984. Anisotropy of the lithosphere from the observations of SKS and SKKS (in Russian). Dokl. Akad. Nauk SSSR, 78: 1335-1339.

Vinnik, L.P., Kind, R., Kosarev, G.L. and Makeyeva, L.I., 1989a. Azimuthal anisotropy in the lithosphere from observations of long-period S-waves. Geophys. J. Int., 99: 549-559.

Vinnik, L.P., Farra, V. and Romanovicz, B., 1989b. Azimuthal anisotropy in the Earth from observations of SKS at GEOSCOPE and NARS broadband stations. Bull. Seismol. Soc. Am., 79: 1542-1558.

Vissers, R.L.M., 1992. Variscan extension in the Pyrenees. Tectonics, 11: 1369-1384

Wilson, J.T.. 1966. Did the Atlantic close and then re-open? Nature, 211: 676-681.

Zwart, H.J., 1986. The Variscan geology of the Pyrenees. Tectonophysics, 129: 9-27. 